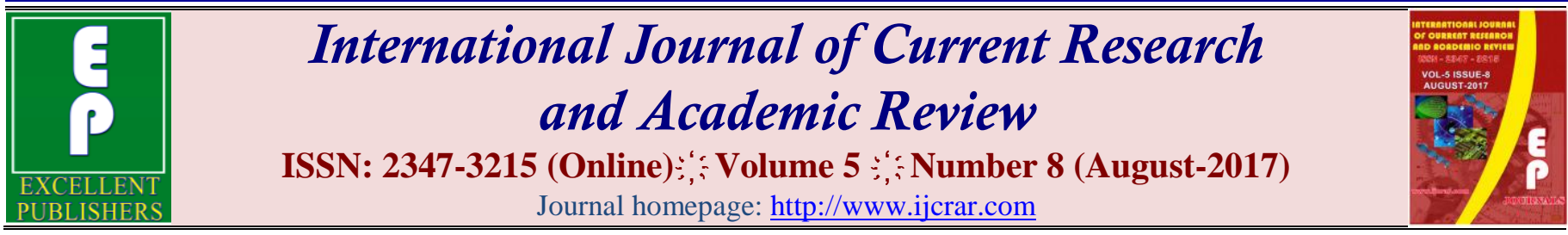

doi: https://doi.org/10.20546/ijcrar.2017.508.006

\title{
Response of Hybrid Sunflower cv. Sunbred to Integrated Nutrient Management Practices
}

\author{
C. Kalaiyarasan", S. Jawahar, K. Suseendran and M. V. Sriramachandrasekharan
}

Department of Agronomy, Faculty of Agriculture, Annamalai University, Annamalai Nagar - 608 002, Tamil Nadu, India

*Corresponding author

\section{Abstract}

A pot culture experiment was conducted at Experimental Farm, Department of Agronomy, Annamalai University, Annamalai Nagar, Tamil Nadu, India to study the response of hybrid sunflower to integrated nutrient management practices on the growth and yield and economics of hybrid sunflower during January to April 2015. The experiment consisted of five treatments viz., $\mathrm{T}_{1}$-Control (RDF-recommended dose of fertilizer; 50:90:60 kgs of NPK ha $\left.{ }^{-1}\right), \mathrm{T}_{2}-\mathrm{T}_{1}+$ Vermicompost @ $5 \mathrm{t} \mathrm{ha}^{-1}, \mathrm{~T}_{3}-\mathrm{T}_{2}+$ Foliar spray of silicon@500ml ha ${ }^{-1}, \mathrm{~T}_{4}-\mathrm{T}_{1}+$ Poultry manure @ $5 \mathrm{t} \mathrm{ha}^{-1}, \mathrm{~T}_{5}-\mathrm{T}_{4}+$ Foliar spray of silicon@ $@ 500 \mathrm{ml} \mathrm{ha}^{-1}$. The experiment was laid out by adopting randomized block design and replicated thrice. Among the different treatments tried, $\mathrm{T}_{5}$ significantly increased the growth attributes and yield attributes, yield (seed, stalk and oil yield) and return per rupee invested of hybrid sunflower. This treatment recorded maximum values for growth attributes viz., plant height $(116 \mathrm{~cm})$ at harvest, Leaf area index (5.90) at flowering, Dry matter production (3926 kg ha ${ }^{-1}$ ) at harvest, brings earliness in $50 \%$ flowering (51.12 days) and total chlorophyll content (2.16) at 60 DAS, and yield attributes viz., head diameter $(13.5 \mathrm{~cm})$, number of seeds $\operatorname{head}^{-1}(680)$ and hundred seed weight (4.54gm) and seed $\left(1525 \mathrm{~kg} \mathrm{ha}^{-1}\right)$ and stalk yield (3500 kg ha-1). This treatment also recorded maximum oil yield with $575 \mathrm{~kg} \mathrm{ha}^{-1}$ and maximum return per rupee invested (2.81). This treatment was closely followed by $\mathrm{T}_{3}$. $\mathrm{T}_{1}$ recorded lowest values for plant height $(80.3 \mathrm{~cm})$ at harvest, LAI (3.49) at flowering, DMP $\left(2051 \mathrm{~kg} \mathrm{ha}^{-1}\right)$ at harvest, delayed flowering (61.24 days) and total chlorophyll content (1.31) and yield attributes viz., head diameter $(8.9 \mathrm{~cm})$, number of seeds head ${ }^{-1}(460)$ and hundred seed weight $(2.9 \mathrm{gm})$ and seed $\left(980 \mathrm{~kg} \mathrm{ha}^{-1}\right)$ and stalk yield $(2570 \mathrm{~kg}$ ha ${ }^{1}$ ) and oil yield $\left(370 \mathrm{~kg} \mathrm{ha}^{-1}\right)$. $\mathrm{T}_{1}$ also registered minimum values for return per rupee invested with 1.48.
\end{abstract}

\section{Article Info}

Accepted: 30 July 2017

Available Online: 20 August 2017

\section{Keywords}

Sunflower,

Nutrient management,

Experiment,

Silicon

\section{Introduction}

Sunflower [Helianthus annuus L.], the major oilseeds crops of India forms essential part of human diet, besides it produces basic raw materials for agro - based industries. The crop has large acreage covering 20.7 million ha in different agro - climatic zones of this country. Sunflower holds great promise as an oilseed crop because of its short duration, photo - in sensitivity, and wide adaptability to different agroclimatic regions and soil types. Sunflower seed contains about $48-53$ percent edible oil. Sunflower oil is a rich source of linoleic acid (64 percent) which is good for heart patients. The oil is also used for manufacturing hydrogenated oil. It can be grown at any time of the year and can serve as an ideal catch crop during the period when the land is otherwise fallow. Sunflower best suits such conditions, with chances of area expansion and horizontal intensification for improving oil seed production in India. Sunflower can play an important role in meeting out the shortage of edible oils in the country. At present, the sunflower productivity in India and Tamilnadu is very low, mainly because of the suboptimal soil fertility. Nutrient removal by crops far 
exceeds than the nutrient addition through fertilizer. To this extent, the soils are becoming depleted, because inch of this gap is at the expense of soil fertility. Application of fertilizers having nutrients like nitrogen, phosphorus and potash can increase sunflower growth and yield substantially. Nitrogen, phosphorus and potash (NPK) ratio is an important indicator in crop production that identified balanced (or) unbalanced fertilization. Inorganic fertilizers have the main advantage of providing nutrients in crop quickly available, while their cost and risk to degrade the environment are among the main disadvantages; therefore they are often replaced by organic manures and composts.

Ever since the role of soil fertility in crop production has been recognized, the use of organic manures has become an imperative need for successful farming. Organic manures adds considerable amount of macro and micronutrients besides improving soil structure through increased aggregation, which favorably influences the water infiltration, moisture retention, aeration and penetration of root. Utilization of all possible sources of organic matter such as vermicompost, farm yard manure and poultry manure helps in improving the soil fertility status and also enhances the yield of the crops. Silicon is the second most abundant element of the earth's surface and plays a significant role in imparting biotic, abiotic stress resistance and enhancing crop productivity. In recent years, silicon has been regarded as a quasi essential element (Epstin, 1999) which increases crop production and quality, increases plant ' $\mathrm{P}$ ' nutrition, reduces $\mathrm{N}, \mathrm{P}$ and $\mathrm{K}$ reaching from cultivated areas and improves soil fertility (Matichenkov et al., 2001). The escalated cost of inorganic fertilizers necessitates an imperative need to integrate organic manures along with inorganic fertilizers to minimize the cost of cultivation and realize maximum returns. Hence, the present investigation was carried out to study the effect of organic and inorganic manures along with foliar spray of silicon on growth and yield of hybrid sunflower.

\section{Materials and Methods}

A pot culture experiment was conducted at Experimental Farm, Department of Agronomy, Annamalai University, Annamalai Nagar, Tamil Nadu, India to study the effect of organics and inorganics in conjunction with foliar spraying of silicon on the growth and yield of hybrid sunflower during January to April 2015. The experiment consisted of five treatments viz., $\mathrm{T}_{1}$-Control (RDFrecommended dose of fertilizer; 50:90:60 kgs of NPK ha ${ }^{-}$ ${ }^{1}$ ), $\mathrm{T}_{2}-\mathrm{T}_{1}+$ Vermicompost @ $5 \mathrm{tha}^{-1}, \mathrm{~T}_{3}-\mathrm{T}_{2}+$ Foliar spray of silicon@ @500ml ha ${ }^{-1}, \mathrm{~T}_{4}-\mathrm{T}_{1}+$ Poultry manure @ 5t ha ${ }^{1}, \mathrm{~T}_{5}-\mathrm{T}_{4}+$ Foliar spray of silicon@ $@ 500 \mathrm{ml} \mathrm{ha}^{-1}$. The experiment was conducted by adopting randomized block design (RBD) with three replications. The organic manures viz., vermicompost $\left(5 \mathrm{t} \mathrm{ha}^{-1}\right)$ and poultry manure $\left(5 \mathrm{t} \mathrm{ha}^{-1}\right)$ were applied basally as per recommendation. The crop was fertilized with 50:90:60 $\mathrm{kgs}$ of NPK ha- ${ }^{-1}$. The entire dose of NPK was applied through urea, super and $\mathrm{Kcl}$ as basal as per treatment schedule. Foliar spraying of silicon was done @ $000 \mathrm{ml}$ ha in 500 lits of water. Sunflower hybrid viz., sunbred was sown at a spacing of $60 \times 30 \mathrm{~cm}$ with one seed per hole at $3 \mathrm{~cm}$ depth. The crop was irrigated by means of rose cane. Biometric observations viz., plant height, leaf area index (LAI), dry matter production (DMP), days to $50 \%$ flowering and total chlorophyll content were taken at various growth stages. Plant height was recorded by measuring the plant height from ground level to tip of the top leaf. For leaf area index, the leaf length and breadth of third leaf from top was measured. For measuring DMP, the green plants were kept under $75^{\circ} \mathrm{C}$ in hot air oven for 48 hours and then dry weight is measured and expressed in $\mathrm{kg} \mathrm{ha}^{-1}$. The total chlorophyll content of leaves was determined by using 80 per cent acetone extraction suggested by Arnon (1941). The plants are harvested at 80 days after sowing and then the yield components such as head diameter, number of seeds head $^{-1}$ and test weight (100 seed weight) were recorded. Later, the seeds were sun dried to $10 \%$ moisture content and then seed and stalk yield were recorded and expressed in $\mathrm{kg} \mathrm{ha}^{-1}$. Oil yield was calculated by multiplying seed yield with oil content.

\section{Results and Discussion}

\section{Growth Attributes (Table 1)}

All the treatments significantly increased the growth attributes of sunflower over control $\left(\mathrm{T}_{1}\right)$. Among the various treatments tried, $\mathrm{T}_{5}$ significantly recorded maximum plant height $(116.4 \mathrm{~cm})$ at harvest, LA1 (5.90) at flowering, DMP (3926 kg ha $\mathrm{kg}^{-1}$ at harvest. This treatments also brings earliness in flowering (51.12 days) and recorded highest total chlorophyll content (2.16). This was followed by $T_{3}$. The reasons for the increased values in the treatment might due to be due to balanced supply of nutrients through poultry manure with NPK and silicon. Increase in growth attributes might owe to increased cell division, elongation and expansion caused by silicon (Chandrashekar, 2008). The lowest values were recorded under $T_{1}$. This was evidenced through the studies of Subha and Gajendra Giri (2004). 
Table.1 Growth and yield of hybrid sunflower to integrated nutrient management practices

\begin{tabular}{|c|c|c|c|c|c|c|c|c|c|c|c|c|}
\hline Treatments & $\begin{array}{c}\text { Plant } \\
\text { height } \\
(\mathrm{cm}) \\
\text { (At } \\
\text { harvest) }\end{array}$ & $\begin{array}{c}\text { LA1 } \\
\text { (At } \\
\text { flowering) }\end{array}$ & $\begin{array}{c}\text { DMP } \\
\left(\mathrm{kg} \mathrm{ha}^{-1}\right) \\
(\text { At } \\
\text { harvest })\end{array}$ & $\begin{array}{c}\text { Days to } \\
50 \% \\
\text { flowering }\end{array}$ & $\begin{array}{c}\text { Total } \\
\text { chlorophyll } \\
\text { content }\end{array}$ & $\begin{array}{c}\text { Head } \\
\text { Diameter } \\
(\mathbf{c m})\end{array}$ & $\begin{array}{c}\text { Number } \\
\text { of seeds } \\
\text { head }^{-1}\end{array}$ & $\begin{array}{c}\text { Test } \\
\text { weight } \\
\text { (g) }\end{array}$ & $\begin{array}{c}\text { Seed } \\
\text { Yield } \\
\left(\mathrm{kg} \mathrm{ha}^{-1}\right)\end{array}$ & $\begin{array}{l}\text { Stalk yield } \\
\left(\mathrm{kg} \mathrm{ha}^{-1}\right)\end{array}$ & $\begin{array}{c}\text { Oil yield } \\
\left(\mathrm{kg} \mathrm{ha}^{-1}\right)\end{array}$ & $\begin{array}{c}\text { Return } \\
\text { per } \\
\text { rupee } \\
\text { invested }\end{array}$ \\
\hline $\mathrm{T}_{1}$ & 80.3 & 3.49 & 2051 & 61.21 & 1.31 & 8.4 & 460 & 2.90 & 980 & 2570 & 370 & 1.48 \\
\hline $\mathrm{T}_{2}$ & 85.4 & 3.80 & 2980 & 59.31 & 1.58 & 8.9 & 490 & 3.50 & 1020 & 2680 & 410 & 1.91 \\
\hline $\mathrm{T}_{3}$ & 108.1 & 4.80 & 3626 & 54.21 & 1.89 & 11.54 & 530 & 4.04 & 1235 & 3400 & 515 & 2.44 \\
\hline $\mathrm{T}_{4}$ & 98.8 & 4.00 & 3325 & 56.21 & 1.72 & 9.64 & 580 & 3.65 & 1035 & 2870 & 470 & 2.40 \\
\hline $\mathrm{T}_{5}$ & 116.4 & 5.90 & 3926 & 51.12 & 2.16 & 13.45 & 680 & 4.54 & 1525 & 3500 & 575 & 2.81 \\
\hline SEd & 5.98 & 0.001 & 55.97 & 0.32 & 0.013 & 0.74 & 20.94 & 0.22 & 45.9 & 52.84 & 21.21 & \\
\hline $\begin{array}{c}C D \\
(p=0.05)\end{array}$ & 11.03 & 0.0033 & 112.5 & 0.65 & 0.028 & 1.48 & 42.1 & 0.45 & 92.35 & 106.21 & 42.63 & \\
\hline
\end{tabular}




\section{Yield and economics (Table 1)}

Application of different sources of manures and spraying of silicon had a significant effect on yield attributes and yield and economics of hybrid sunflower. Among the various treatments tried, $\mathrm{T}_{5}$ recorded higher values for yield attributes and yield than other treatments. This treatment registered maximum head diameter (13.45 $\mathrm{cm})$, higher number of seeds head ${ }^{-1}(680)$ and test weight $(4.54 \mathrm{~g})$ and seed yield $\left(1525 \mathrm{~kg} \mathrm{ha}^{-1}\right)$, stalk yield (3500 $\left.\mathrm{kg} \mathrm{ha}^{-1}\right)$ and oil yield $\left(575 \mathrm{~kg} \mathrm{ha}^{-1}\right)$. This treatment also registered maximum return per rupee invested of 2.81 over rest of treatments. This might be due to better assimilation of carbohydrate in sunflower due to poultry manure and NPK with silicon leads to efficient translocation resulted in more number of seeds head ${ }^{-1}$ and increased test weight, which ultimately lead to higher seed and stalk yield and oil yield. Control treatment $\left(\mathrm{T}_{1}\right)$ recorded minimum values for yield attributes and yield of hybrid sunflower. These findings were earlier reported by Sarkar and Mallic (2009).

\section{References}

Arnon, D.I., 1941. Copper enzymes is isolated chloroplasts polyphenol oxidase in Beta vulgaris. Plant Physiol., 24: 1-5.

Chandrashekar, N., 2008. Ineraction of Silicon and Nitrogen in aerobic rice cultivation. M.Sc $(\mathrm{Ag})$ Thesis, UAS, Bangalore, India.

Epstein, E., 1999. Silicon. Annu. Rev. Plant. Physio. Plant. Mol. Biol. 50: 641-644

Matichenkov, V.V., E.A. Bochornikova and J.M. Ammosova. 2001. Influence of silicon fertilizes on the plant soils. Agro chemistry, 12: 30-37

Sarkar, R.K., and R.B. Mallic. 2009. Effect of nitrogen, sulphur and foliar spray of nitrate salts on performance of spring sunflower. Ind. J. Agric. Sci. 79(12): 986-90.

Subha, K.M., and Gagendra Giri. 2004. Effect of INM on dry matter accumulation, Nutrient content and uptake of Sunflower Ann. Agric. Res. 25(3): 398402.

\section{How to cite this article:}

Kalaiyarasan C., S. Jawahar, K. Suseendran and Sriramachandrasekharan M. V. 2017. Response of Hybrid Sunflower cv. Sunbred to Integrated Nutrient Management Practices. Int.J.Curr.Res.Aca.Rev. 5(8), 39-42. doi: https://doi.org/10.20546/ijcrar.2017.508.006 